\title{
Evaluating the Effects of Employee Motivation on Organizational Performance of XXX Limited
}

\author{
ABDUL-RAZAK ABUBAKARI \\ Senior Lecturer, Tamale Technical University \\ Email: aabdul-razak@tatu.edu.gh \\ Tel: 0244772040 \\ BASHIRAT ADAM \\ Bonzali Rural Bank \\ Email: adambashirat@yahoo.com \\ Tel: 0243223791
}

\begin{abstract}
This research evaluated the effects of employee motivation on organisational performance. A quantitative approach and a case study were employed. Asample of 92 employees researched on from a population of 120 employees in XXX Limited (not the real name). A structured questionnaire was adopted for primary data collection. The study found that there were both monetary and non-monetary motivational strategies adopted by XXX Limited. Specifically noted were the employees' salary scheme, bonuses, promotion and good interpersonal relationship among staff. The study found that employee motivation has positive influence on the performance of the employee and the organization at large. Also, motivational factors adopted by XXX Limited has significant influence on employees' performance. It is envisaged that if motivational strategies are collectively determined and enforced, employees' and organizational performance would be sustainably enhanced.
\end{abstract}

Keywords: Employee, Motivation, Organization, Performance and Motivational Strategies.

\section{Introduction}

Every organization in its aim to achieve its mission and vision statements adopts some form of motivational strategies to entice their employees to give off their best. Some organizations assume that whatever motivational strategies that they adopt would fit for every employee and bring about achievement of their performance targets. This to Bruce (2006), most managers generalize the needs of their employees. This generalization is what leads to dismal performances in most organizations. However, when organizations do not make the effort to understand what motivates their employees they do not get the best out of them in terms of productivity, profitability and longtime survival of the organization among others (Lawler, 2003; Shadare \& Hammed; Davis, 2010; McFarland, 2012).

Morse (2003) states that managers are not as good at judging employee motivation as they think they are. In fact, people from all walks of life seem to consistently misunderstand what drives employee motivation. XXX Limited is no different from those organizations in that motivational strategies applied are generic in nature and no effort has been made to research into the effects of employees' motivation on the performance of the organization. All proponents of motivation agree that the employees' need, interest must be known in order to determine how to effectively motivate them to achieve organizational 
performance. It is against this background that this research is conducted to evaluate the effects of employees' motivation on the performance of the XXX Limited.

\section{Objective and Significance of the Study}

The general objective of the research is to evaluate the effects of employees' motivation on the performance of XXX Limited.

The timeliness and appropriateness of this study cannot be overemphasized because of the complex nature of competition arising from changing economic environment of Tamale where the influx of banks has been on the increase. The research would help managers to be aware of the effect of their actions and inactions towards employee motivation. Thus, the outcome of the study serves as a guide for corporate organizations to adopt appropriate motivational strategies to enhance their performance. In addition, the results of the study would contribute to the existing body of knowledge in the area of motivation and would also provide a basis upon which further researches would be carried out. Also, the results would help XXX Limited to adopt the right mix of motivational strategies to enhance their performance especially as the influx of banks in the Tamale metropolis exposes the organization to stiff competition.

\section{Literature Review}

\section{Motivation}

To Guay (2010) motivation is the reason underlying behavior. Also, motivation can be defined as the purpose or psychological cause of an action (Schater, 2011). Slocum et al., (2007), motivation represents the forces acting on or within a person that cause the person to behave in a specific goal directed manner.

Motivation is an important phenomenon because it helps to throw more light into why human beings behave and act in a certain way. Thus, it explains what drove Thomas Edison to invent the first light bulb, Maya Angelou to write poetry and Nelson Mandela to become the president of South Africa (Grant \& Shin ,2011). Motivation is easy to understand but difficult to define because of the numerous interpretation that is given to it by different authors who themselves are influenced by what they think it ought to be.

The definition of motivation has evolved from the days of Taylor et al. (1911) to Maslow (1943) to Nevid (2013); however, what is common in all the definitions is that all the authors believe that there are stimuli, push, and drive among others that propel human beings to act in a particular way. Motivation therefore is defined as the inner force that drives people's level of effort, determination and energy in the face of obstacles, impediments to accomplish a goal.

Employee motivation is one of the policies of managers to increase effectual job management amongst employees in organizations (Shadare et al., 2009). One of the ways to get people to like working hard is to motivate them. Today, people must understand why they are working hard. Every individual in an organization is motivated by something different (Pitino, 2013). Employee motivation is a reflection of the level of energy, commitment, and creativity that a company's workers bring to their jobs (Wilks, 2012).

\section{Organisation and Organizational Performance}

An Organisation is group of individuals, large or small, that is cooperating under the direction of executive leadership in accomplishment of certain common object (Davis, 2010). McFarland (2012) added that an organization is an identifiable group of people contributing their efforts towards their attainment of goals. Organisation performance has evolved overtime.In the 1950s organizational performance was defined as the extent to which organizations, viewed as a social system, fulfilled their objectives (Georgopoulos\&Tannenbaum, 1957). Performance was based on work, people and organizational structure. 
Later in the 60s and 70s, organizations have begun to explore new ways to evaluate their performance so performance was defined as an organization's ability to exploit its environment for accessing and using the limited resources (Yuchtman \& Seashore, 1967) as cited in (Gavrea et al., 2011).

The 80s and 90s were marked by the realization that the identification of organizational objectives is more complex than initially considered. Managers began to understand that an organization is successful if it accomplishes its goals (effectiveness) using a minimum of resources (efficiency). Thus, organizational theories that followed supported the idea of an organization that achieves its performance objectives based on the constraints imposed by the limited resources (Lusthaus\& Adrien, 1998). In this context, profit became one of the many indicators of performance as cited in (Gavrea et al., 2011).

After the 90's other definitions came out and according to Pitt and Tucker (2008), organizational performance is defined as a vital sign of the organization, showing how well activities within a process or the outputs of a process achieve a specific goal. Boxall and Steeneveld (1999) on the other hand argued that there is no need to prove the relationship between firm critical influence on performance and labor management as it is self-evident that the quality of human resource management is a critical influence on the performance of the firm. Organizational performance encompasses three specific areas of firm outcomes: financial performance (profits, return on assets, return on investment, etc.); market performance (sales, market share, etc.); and shareholder return (total shareholder return).

Organizational performance is therefore the efficiency and effectiveness displayed in achieving enhanced profits, productivity, sales, innovativeness and increase in market share and shareholder wealth maximization.

\section{Effects of Employee Motivation on Organizational Performance}

Employee motivation cannot be examined in isolation from its organizational context since it is the activities undertaken within an organization that are being considered; and in particular it is human motivation that encourages the individual to remain with the organization (Schepers et. al., 2005). Lawler (2003) argued that prosperity and survival of the organizations is determined through and how they treat their human resource.

There is one key to profitability and stability during either a boom or bust economy: employee morale (Sirota, 2005). Wiley (1997) suggests that ensuring the success of a company, employers must understand what motivates their employees, and such understanding is essential to improving productivity. Similarly, a motivated employee is more likely to output more to the benefit of the organization (Shadare \& Hammed, 2000). When the employees are motivated, it leads to increase in the quantity and quality of output produced. This is because the motivation results in greater personal effort and devotion on the part of the employees (Onukwufor \& Ugwu, 2013). The reverse is true, as seen in Crawford et al. (2010) who stated that the absence of employee motivation is frustrating as it will slow the schedule down and even terminate the project, which would have a big burden of cost for the company.

Employee absenteeism has long been recognized as a major problem for organizations of all types (Markowich \&Eckberg, 1996) and empirically has been shown to reduce organizational efficiency and productivity (Moch \& Fitzgibbons, 1985) as cited in (Libet et al., 2001). Hirschfield (2002) asserted that employees who perceive limited or few performance reward expectancies were more likely to be absent from work very often. Also, Crawford et al. (2010) contend that whiles employers expect workers to miss certain number of workdays each year, excessive absence can equate to decreased productivity and can have a major effect on company finances, morale and other factors.

Garino and Martin (2008) analyzed the impact of labor turnover on profit using the efficiency wage model of Salop (1979) by separating incumbent and newly hired workers in the production function. They showed 
that an exogenous increase in turnover rate can affect increase in profit, but only where organizations do not choose the wage. Kemal et al. (2002) also expressed similar thoughts that the cost of turnover affects the profitability of the organization, customer service and satisfaction. In a nutshell, a satisfied employee is one who is well motivated personally and by their organizations and have no desire to seek greener pastures anywhere.

\section{Methodology}

Quantitative approach was used which involved the use of structured questionnaires. The study population was the staff (120) of XXX Limited who has been divided into executive, middle and lower level management to get each level's perception on the research topic. A sample of 92 staff was drawn from the target population. Probability sampling, thus simple random sampling technique was adopted because it affords reduction of bias in sampling where each staff had equal chance of being chosen. The Yamane (1967) formula was used to determine the sample size. Thus Frequencies, percentages, graphs, ANOVA table, and correlation and regression tables were used in the presentation and analysis of data.

Table 1: Categories of Respondents to the questionnaires

\begin{tabular}{|c|c|c|}
\hline Levels Of Management & Population & Sample Size \\
\hline Executive Management & 7 & 5 \\
\hline Middle Management & 26 & 20 \\
\hline Lower Management & 87 & 67 \\
\hline Total & $\mathbf{1 2 0}$ & $\mathbf{9 2}$ \\
\hline
\end{tabular}

Source: Human Resource Department, XXX Ltd(June 2015)

\section{Analysis and Discussions}

\section{Demographics of Staff}

From the survey, it is revealed that $26 \%$ of the respondents for the study were females whiles $74 \%$ were males. This suggests that there are far more men than women working in XXX Ltd. Table 2 presents data on the gender representation of the workforce of the XXX Ltd.

Table 2: Demographic Data of Respondents

\begin{tabular}{|c|c|c|}
\hline Gender & Frequency & Percentage \\
\hline Male & 68 & 74 \\
\hline Female & 24 & 26 \\
\hline Total & 92 & 100 \\
\hline Age & Frequency & Percentage \\
\hline 21-30 years & 18 & 20 \\
\hline $31-40$ years & 66 & 71 \\
\hline $41-50$ years & 6 & 7 \\
\hline 50 year and above & 2 & 2 \\
\hline Education & Frequency & Percentage \\
\hline SSCE & 8 & 9 \\
\hline Diploma & 44 & 48 \\
\hline Bachelor & 29 & 32 \\
\hline Masters & 4 & 4 \\
\hline Professional & 6 & 7 \\
\hline & 92 & 100 \\
\hline
\end{tabular}

Source, Field survey2015. 
With regards to the age distribution of the workforce of the XXX Ltd, it was found that $20 \%$ aged between 21 and 30 years whiles $71 \%$ aged between 31 and 40 years. Staffs between the ages of 41 and 50 were noted to have been represented by $7 \%$ of the respondents. Staff ageing above 50 years were also represented by $2 \%$ of the respondents. It shows that, the workforce of the XXX Limited is largely a youthful one (i.e. densely situated within the ages of 21 and 40 years). Since the active workforce of Ghana is of this range, it presupposes that the human resource of the XXX Ltd is an active one. Table 2 presents the age distributions of the respondents.

In terms of respondents' academic attainment, the survey found that $9 \%$ of the workforce of the XXX Ltd had their highest academic qualifications equivalent to the Senior Secondary School Certificate and below. Also, $48 \%$ of the workforce acquired Diploma in various fields of studies while $32 \%$ of the respondents had $1^{\text {st }}$ Degree in varying fields of study. The survey also showed that workers with Masters degree represent $4 \%$ of the workforce while workers with professional qualifications represent $7 \%$ of the workforce. It suggests that the workforce of the XXX Limited is a well-educated one and would have adequate understanding of the concept of motivation and how it influences performance. Table 2 illustrates data on the academic attainments of the workforce of the bank.

\section{Effects of the adopted Motivational Strategies on the XXX Itd Performance}

An enquiry to ascertain how employees believe their motivation influences the performance of the organization, it was noted that employee motivation has strong effects on the performance of an organization. The survey found that, profitability, productivity, market share, innovativeness, shareholders' worth, sales and liquidity are all influenced greatly by employee motivation. Specifically, the influence of employee motivation is most felt through increasing profitability and productivity. Also, all other performance indicators as listed in Table 3 are influenced by employee motivation. It tells that, employee motivation has that favorable effect on organization performance. These findings buttress the positions of Wiley (1997); Shadare and Hammed (2000); Onukwufor and Ugwu (2013); Garino and Martin (2007) as they found favourable impacts and relations between employee motivation and organizational performance. Table 3 shows data to these responses.

Table 3: Effects of Employee Motivation on Organizational Performance

\begin{tabular}{|c|c|c|c|c|c|c|}
\hline $\mathrm{S} / \mathrm{N}$ & Variables & $\begin{array}{c}\text { Strongly } \\
\text { Agree }\end{array}$ & Agree & Neutral & $\begin{array}{c}\text { Strongly } \\
\text { Disagree }\end{array}$ & Disagree \\
\hline 1 & Increase in Profitability & $63.00 \%$ & $19.60 \%$ & $15.20 \%$ & $0.00 \%$ & $2.20 \%$ \\
\hline 2 & Increase in Productivity & $56.50 \%$ & $26.10 \%$ & $15.20 \%$ & $0.00 \%$ & $2.20 \%$ \\
\hline 3 & Increase in Market Share & $23.90 \%$ & $41.30 \%$ & $32.60 \%$ & $0.00 \%$ & $2.20 \%$ \\
\hline 4 & Employee Innovativeness & $32.60 \%$ & $37.00 \%$ & $28.30 \%$ & $0.00 \%$ & $2.20 \%$ \\
\hline 5 & Increase in Shareholders worth & $28.30 \%$ & $43.50 \%$ & $28.30 \%$ & $0.00 \%$ & $0.00 \%$ \\
\hline 6 & Increase in sales & $39.10 \%$ & $37.00 \%$ & $21.70 \%$ & $0.00 \%$ & $2.20 \%$ \\
\hline 7 & Increase in Liquidity & $41.30 \%$ & $21.70 \%$ & $28.30 \%$ & $0.00 \%$ & $2.20 \%$ \\
\hline
\end{tabular}

Source: Field survey, June 2015.

\section{Correlation Analysis between Adopted Key Motivators and Performance Indicators}

From Table 4, it can be observed that there is a statistically positive significant correlation between organizational performance as represented by the key indicators compressed as effects and the motivation of employees. The ' $p$ ' value for the correlation was 0.016 which is less than 0.5 , thereby signifying that there is a real positive relationship between employee motivation and organizational performance. The positive correlation thus means that, the more employees are motivated, the more improved their performance and for that matter, the performance of the organization would be. 
The ' $r$ ' value of 0.250 which depicts a weak positive correlation between employee motivation and performance. This suggests that, the adopted strategies were either not appropriate for the employees or ineffectively administered. Indeed, motivation is worth giving attention since it induces positive effects for the organization. This is why Grey and Manske (2012) cautioned that, motivation myth is the simple yet powerful key to unlock human potential and create inspired performance and achievement. Refer to correlations table in Appendix 1 for more data on correlations between employee motivation and organizational performance.

Table 4: Correlation Analysis of Employee Motivation and Organizational Performance

\begin{tabular}{|c|c|c|}
\hline \multicolumn{2}{|c|}{ Pearson Correlation Analysis } & Effects \\
\hline Key motivators & Pearson Correlation & $.250^{*}$ \\
\hline & Sig. (2-tailed) & .016 \\
\hline & $\mathrm{N}$ & 92 \\
\hline
\end{tabular}

*. Correlation is significant at the 0.05 level (2-tailed).

The views held above are further reiterated in a regression analysis using the performance indicators (labeled 'effects') as dependent variables and the independent variables as the adopted factors of motivation at the XXX Ltd.

The regression analysis showed that the dependent variable (performance indicators-effects) can be explained by the independent variable. But it could explain only $0.063(6.3 \%)$ of organizational performance. It tells further that, the adopted factors could not motivate employees well enough to produce the needed performance.

The result also suggests that XXX Ltd is currently not at its best performance which needs to be looked at for the continued survival of the organization. The quality of the model to predict the dependent variable is shown by the ' $R$ ' value shown in the model $(0.250)$, similar to the ' $r$ ' value obtained in the correlation analysis. Table 5 is the summary of the regression model.

\section{Table 5: Model Summary}

\begin{tabular}{|c|c|c|c|c|}
\hline Model & $\mathrm{R}$ & R Square & Adjusted R Square & Std. Error of the Estimate \\
\hline 1 & $.250^{\mathrm{a}}$ & .063 & .052 & 4.647 \\
\hline
\end{tabular}

a. Predictors: (Constant), Key motivators

The ANOVA on Table 6 also shows that the model is significant in predicting the dependent variable (performance indicators-effects). A 'p-value' of 0.16 was obtained and $F(1,90)=21.598$, depicting that model is reliable in determining the relationship between employee motivation and the adopted motivational factors and its effects as shown in the performance indicators.

Table 6: ANOVA $^{\mathrm{b}}$

\begin{tabular}{|c|c|c|c|c|c|c|}
\hline & Model & Sum of Squares & Df & Mean Square & $\mathrm{F}$ & Sig. \\
\hline \multirow[t]{3}{*}{1} & Regression & 130.104 & 1 & 130.104 & 6.024 & $.016^{\mathrm{a}}$ \\
\hline & Residual & 1943.809 & 90 & 21.598 & & \\
\hline & Total & 2073.913 & 91 & & & \\
\hline
\end{tabular}

a. Predictors: (Constant), Key motivators

b. Dependent Variable: Effects 


\section{Conclusions}

XXX Ltd has a couple of motivational strategies in place to enhance employees and organisational performance. These strategies included attractive salary schemes, bonuses, promotion, amongst others. So many employees were however not satisfied with the strategies adopted.

Nonetheless, these strategies were based on the educational level of staff, their ability to achieve set targets, strength of internal controls, amongst others. Interestingly, employees preferred motivational strategies to be based on staff education and quality of work and also experience. By these suggestions of employees, a little more focus on job security, salary, bonus, and interpersonal issues could make a difference in employee performance.

The actual motivational factors at work in XXX Ltd are salary, bonuses, promotion, job security, opportunity for growth and responsibility. It can be concluded therefore that; employee motivation has the tendency to predict a significant positive effect on organizational performance. Hence, there is the need to re-strategize and ensure that employees are really motivated to yield the best of results they could.

\section{Recommendations}

Regarding the functionality of the motivational factors adopted by XXX ltd, the study suggests that focus should be on the real motivators of its employees which are attractive salary schemes, security of job, bonuses in the form of allowances, promotion, recognition and an enabling atmosphere where everyone is treated fairly which enhances good interpersonal relations.

The firm may not have to adopt several factors especially when the capacity to ensure their effective management is not readily available. However, employees would rather be satisfied with a few motivational factors effectively applied than several factors poorly administered.

For motivational factors to remain relevant and boost organizational performance since they are interrelated, a system should be put in place to track and ensure that the adopted factors are producing desired results. The study therefore recommends periodic assessments to be carried out among the entire staff of the firm regarding the various packages in place where feedback from the assessment is used to enhance the motivational factors package in place.

The firm should consider employee recognition strongly by instituting employee of the month recognition scheme for each branch where employees' zeal, commitment and targets are considered in coming out with the winner. This would ensure the realization of the organizational performance at all times because individual efforts are regularly being appreciated and there is healthy competition amongst employees to always win thereby improving the performance of the organization.

\section{References}

Arrowsmith J, Edwards, T, \& Sisson, K. (2000). Industrial relations at British Airways - setting a new course?European Industrial Relations Observatory (EIRO).

Anders, D. \&Bård, K. (2010). "Exploring the relative and combined influence ofMastery-approach goals and work intrinsic motivation on employee turnover intention",Personnel Review, Vol. 39 Iss: 5, pp. $622-638$.

Boxall, P. \&Steeneveld, M. (1999). Human Resource Strategy and Competitive Advantage: A Longitudinal Study of Engineering Consultancies'. .Journal of Management studies, Vol. 36, No. 4:443-463.

Bruce, A. (2006). How to Motivate Employees: 24 Proven Tactics to Spark Productivity in theWorkplace. NY, McGraw Hill Professional. 
Crawford, E. R., LePine, J. A., \& Rich, B. L. (2010). Linking job demands and resources toemployee engagement and burnout: A theoretical extension and meta-analytic test. Journal of Applied Psychology, $95,834-848$.

Frey, B. S. (1997a). A Constitution for Knaves Crowds out Civic Virtues. Economic Journal, 107(443): 1043-1053.

Frey, B. S., \& Jegen, R. (2001). Motivation crowding theory: A survey of empirical evidence. Journal of Economic Surveys, 15(5): 589-611.

Garino, G. \& Martin, C. (2008). The Impact of Labour Turnover: Theory and Evidence from UK Micro Data, Quantitative and Qualitative Analysis in the Social Sciences, 1(3), 81-104.

Gavrea et al (2012). Business Strategy, structure and organizational performance, Studia UBB Negotia, LVII.

Gavrea, C., Ilies, L. \&Stegerean, R. (2011). Determinants of organizational performance: The case of Romania, Management \& Marketing, 6(2): 285-300.

Georgopoulos, B. \&Tannenbaum, A. (1957). A Study of Organizational Effectiveness, American Sociological Review 22: 534-40.

Grant, A.M. \& Shin, J. (2011). Work Motivation: Directing, Energizing and maintaining effort (and research) forthcoming in RM Ryan (Ed.), Oxford handbook of motivation; Oxford university press.

Grey, M \&Manske, J. (2012). The motivation myth: The simple yet powerful key to unlock human potential and create inspired performance and achievement, CreateSpace Independent publishing platform.

Guay, F., Chanal, J., Ratelle, C. F., Marsh, H. W., Larose, S., \&Boivin, M. (2010). Intrinsic, identified and controlled types of motivation for school subjects in young elementary school children.British Journal of Educational Psychology, 80(4): 711-735.

Herzberg, F.(1966). Work and the Nature of Man. Cleveland: World Publishing.

Herzberg, F., Mausner, B. \& Snyderman, B.B. (1959). The Motivation to Work. New York: John Wiley \& Sons.

Hirschfeld, R.R., Schmitt, L.P., \&Bedeian, A.G. (2002). Job-content perceptions, performance-reward expectancies, and absenteeism among low-wage public-sector clerical employees. Journal of Business and Psychology, 16(4), 553-564. http://dx.doi.org/10.1023/A:1015450218211

Kemal, A.R., Din, M., Qadir, U., Fernando, L. \&Colombage, S. (2002). Exports and Economic Growth in South Asia" A Study prepared for the South Asia Network of Economic Research Institutes

Lawler, E. E. (2003). Treat people right. San Francisco: Jossey-Bass Inc. McGraw-Hill Irwin.

Libet, J., Frueh, C., Pellegrin, K., Gold, P., Santos, A. \& Arana, G. (2001). Absenteeism and Productivity among Mental Health Employees.Administration and Policy in Mental Health 29 (1): 41-50.

Lusthaus, C. \& Adrien, (1998) M-H. “Organizational assessment: A review of experience”, Universalia.

Maslow, A. H. (1943). Conflict, frustration, and the theory of threat. J. abnorm. (soc.)Psychol., (38) 81-86.

Morse, G. (2003, January). Why we misread motives? Harvard Business Review. 81(1)18.

Moch, M. K., \& Fitzgibbons, D. E. The relationship between absenteeism and production efficiency: An empirical assessment. Journal of Occupational Psychology, 1985, 58, 39-47.

Markowich, M.M., \&Eckberg, S. (1996). Get control of the absentee-minded.Personnel Journal, 75, 115120.

Nevid, J.S. (2013).Psychology: Concepts and applications, Belmont, CA: Wadsworth Cengage learning.

Onukwufor, J.N. \&Ugwu, C.J. (2013). Counselling for Employee Motivation,Discourse Journal of Educational Research,1(2), 19-25.

Pitino, R. (2013) Brainyquote.com retrieved June 2015 from brainyquote.com. Website: http://www.brainyquote.com/quotes/quotes/rickpitino326962.html

Pitt, M. \& Tucker, M. (2008). Performance measurement in facilities management: driving innovation,Property Management, 26(4): 241-254

Shadare, O. A., \& Hammed, T. A. (2009). Influence of work motivation, leadership effectiveness and time management on employees' performance in some selected industries in Ibadan, Oyo State, Nigeria. European Journal of Economics, Finance and Administrative Sciences, 16, 7-17. 
Sirota, D., Mischkind, L. A., \& Meltzer, M. I. (2005). The enthusiastic employee: how companies profit by giving workers what they want. Indianapolis, IN: Wharton School Pub.

Schepers C., De Gieter, S., Pepermans, R., Du Bois, C., Caers, R., \&Jegers, M. (2005). How are Employees of the Nonprofit Sector Motivated? Nonprofit Management \& Leadership. 16, 2,191-208.

Taylor, F. W. (1911). The Principles of Scientific Management.

Vasconcelos, A.F. (2011). Internal demarketing: Construct, research propositions and managerial implications", Management \& Marketing, 6(1): 35-58.

Wiley, C. (1997), "What Motivates Employees According to Over 40 Years of Motivation Surveys," International Journal of Manpower, 18(3),263-281.

Yuchtman, E. \& Seashore, S. (1967). Factorial Analysis of Organizational Performance, Administrative Science Quarterly, 12(3): 377-95.

Yamane, Taro. 1967. Statistics, An Introductory Analysis, 2nd Ed., New York: Harper and Row. 
Appendix 1: Other Correlation Information

\begin{tabular}{|c|c|c|c|c|c|c|c|c|}
\hline & & $\begin{array}{l}\text { Increase In } \\
\text { Profitability }\end{array}$ & $\begin{array}{l}\text { Increase In } \\
\text { Productivity }\end{array}$ & $\begin{array}{c}\text { Increase In } \\
\text { Market Share }\end{array}$ & $\begin{array}{l}\text { Employee } \\
\text { Innovation }\end{array}$ & $\begin{array}{c}\text { Increase In } \\
\text { Shareholders' } \\
\text { Worth }\end{array}$ & $\begin{array}{c}\text { Increase In } \\
\text { Sales }\end{array}$ & $\begin{array}{c}\text { Increase In } \\
\text { Liquidity }\end{array}$ \\
\hline \multirow[t]{2}{*}{ Salary } & Pearson Correlation & $.278^{* *}$ & .132 & .177 & -.027 & .000 & .020 & -.068 \\
\hline & Sig. (2-tailed) & .007 & 209 & .091 & .801 & 1.000 & .851 & .523 \\
\hline \multirow[t]{2}{*}{ Bonuses } & Pearson Correlation & .094 & .176 & $.209^{*}$ & -.023 & -.120 & -.008 & .006 \\
\hline & Sig. (2-tailed) & .371 & .093 & .046 & .824 & .255 & .938 & .952 \\
\hline \multirow[t]{2}{*}{ Promotion } & Pearson Correlation & -.040 & .111 & .201 & -.153 & .000 & .133 & .124 \\
\hline & Sig. (2-tailed) & .707 & .291 & .055 & .144 & 1.000 & .206 & .240 \\
\hline \multirow[t]{2}{*}{ Recognition } & Pearson Correlation & $.278^{* *}$ & $.227^{*}$ & $.325^{* *}$ & -.018 & .109 & $.243^{*}$ & .166 \\
\hline & Sig. (2-tailed) & .007 & .030 & .002 & .866 & .301 & .019 & .115 \\
\hline \multirow[t]{2}{*}{ Empowerment } & Pearson Correlation & .194 & $.260^{*}$ & $.477^{* *}$ & 041 & $.211^{*}$ & $.269^{* *}$ & $.226^{*}$ \\
\hline & Sig. (2-tailed) & .064 & .012 & .000 & .697 & .043 & .009 & .030 \\
\hline \multirow{2}{*}{$\begin{array}{l}\text { Information } \\
\text { Availability \& } \\
\text { Communication }\end{array}$} & Pearson Correlation & .044 & $.368^{* *}$ & $.399^{* *}$ & $.299^{* *}$ & $.305^{* *}$ & $.395^{* *}$ & $.338^{* *}$ \\
\hline & Sig. (2-tailed) & .674 & .000 & .000 & .004 & .003 & .000 & .001 \\
\hline \multirow[t]{2}{*}{ Appraisal } & Pearson Correlation & -.023 & -.055 & .060 & -.195 & -.035 & -.104 & -.146 \\
\hline & Sig. (2-tailed) & .829 & .603 & .570 & .062 & .742 & .326 & .166 \\
\hline \multirow[t]{2}{*}{ Job Design } & Pearson Correlation & .103 & $.263^{*}$ & .035 & .088 & $.212^{*}$ & $.272^{* *}$ & .202 \\
\hline & Sig. (2-tailed) & .328 & .011 & .743 & .405 & .043 & .009 & .054 \\
\hline \multirow[t]{2}{*}{ Job Security } & Pearson Correlation & $.258^{*}$ & $.414^{* *}$ & $.429^{* * *}$ & .093 & .151 & $.220^{*}$ & $.280^{* *}$ \\
\hline & Sig. (2-tailed) & .013 & .000 & .000 & .377 & .150 & .035 & .007 \\
\hline \multirow{2}{*}{$\begin{array}{l}\text { Quality } \\
\text { Supervision }\end{array}$} & Pearson Correlation & -.114 & .019 & .103 & -.043 & $.245^{*}$ & .159 & .104 \\
\hline & Sig. (2-tailed) & .277 & .855 & .327 & .682 & .019 & .130 & .324 \\
\hline \multirow{2}{*}{$\begin{array}{l}\text { Company } \\
\text { Policy }\end{array}$} & Pearson Correlation & -.011 & $.207^{*}$ & .046 & -.145 & $.311^{* *}$ & $.239^{*}$ & .118 \\
\hline & Sig. (2-tailed) & .920 & .048 & .661 & .167 & .003 & .022 & .261 \\
\hline \multirow{2}{*}{$\begin{array}{l}\text { Challenging } \\
\text { Work }\end{array}$} & Pearson Correlation & -.146 & .054 & $.309^{* * *}$ & $.234^{*}$ & $.300^{* *}$ & .118 & .031 \\
\hline & Sig. (2-tailed) & .164 & .611 & .003 & .025 & .004 & .264 & .769 \\
\hline \multirow{2}{*}{$\begin{array}{l}\text { Opportunity For } \\
\text { Advancement }\end{array}$} & Pearson Correlation & -.076 & -.027 & .112 & -.150 & -.028 & .132 & .009 \\
\hline & Sig. (2-tailed) & .469 & .798 & .289 & .153 & .788 & .208 & .934 \\
\hline \multirow[t]{2}{*}{ Status } & Pearson Correlation & $.224^{*}$ & $.251^{*}$ & $.252^{*}$ & $-.235^{*}$ & .041 & .063 & .005 \\
\hline & Sig. (2-tailed) & .032 & .016 & .016 & .024 & .695 & .550 & .961 \\
\hline \multirow[t]{2}{*}{ Responsibility } & Pearson Correlation & .118 & .122 & .041 & .022 & .037 & -.015 & .036 \\
\hline & Sig. (2-tailed) & .263 & .248 & .696 & .837 & .725 & .887 & .737 \\
\hline \multirow[t]{2}{*}{ Growth } & Pearson Correlation & $.332^{* *}$ & $.428^{* *}$ & .176 & -.033 & .000 & $.251^{*}$ & $.210^{*}$ \\
\hline & Sig. (2-tailed) & .001 & .000 & .093 & .752 & 1.000 & .016 & .045 \\
\hline
\end{tabular}

**. Correlation is significant at the 0.01 level (2-tailed).

*. Correlation is significant at the 0.05 level (2-tailed). 